\title{
A Comparative Analysis of Environmental Management System Implementation in Fertilizer Industries: Case Study of PT Pupuk Kaltim, PT Pupuk Kujang, and PT Petrokimia Gresik
}

\author{
Fahri Fardiansyah $^{1 *}$, Filson Maratur Sidjabat ${ }^{2 *}$ \\ ${ }^{1,2}$ Environmental Engineering Department, President University, Bekasi \\ *Koresponden email: fahri.fardiansyah@student.president.ac.id, fmsidjabat@ president.ac.id
}

Received: June 19, 2021

Approved: 13 Agustus 2021

\begin{abstract}
Considering Indonesia as an agricultural country, it certainly needs a support to have an adequate supply of fertilizer. Currently, the development of the fertilizer industry in Indonesia is quite rapid. Due to a large demand of fertilizers, the fertilizer industry is trying to provide good quality products to ensure customer's satisfaction. In addition to improving product quality, fertilizer producers in Indonesia also strive to environmental management system aspects as an effort to implement ISO 14001:2015. The objective of this study is to analyze the comparison of environmental management system implementation among fertilizer producers in Indonesia, namely PT Pupuk Kaltim, PT Pupuk Kujang, and PT Petrokimia Gresik. The three fertilizer producers were chosen since they had already received ISO 14001: 2015 certification. The method used in this study is a qualitative method by analyzing and interpreting the data that has been obtained. The results show that the implementation strategies in environmental management carried out by the three fertilizer producers are not much different, almost all of them have the same strategy in terms of environmental management. However, PT Pupuk Kaltim has superiority in environmental management compared to its competitors, it is proven by the achievement of the PROPER gold at three consecutive years, while PT Pupuk Kujang and PT Petrokimia Gresik merely achieved the PROPER green category.
\end{abstract}

Keywords: ISO 14001:2015, implementation, fertilizer industry, PROPER, environmental management

\begin{abstract}
Abstrak
Mengingat Indonesia merupakan negara agraris, tentunya harus ditunjang dengan pasokan pupuk yang memadai. Saat ini perkembangan industri pupuk di Indonesia terbilang cukup pesat, karena banyaknya permintaan terhadap pupuk, para produsen pupuk berusaha untuk memberikan kualitas produk yang baik demi kepuasan pelanggan. Selain meningkatkan kualitas mutu produk, produsen pupuk di Indonesia juga memperhatikan aspek sistem manajemen lingkungan sebagai upaya implementasi ISO 14001:2015. Objektif studi ini adalah untuk menganalisis perbandingan implementasi sistem manajemen lingkungan diantara produsen pupuk di Indonesia yakni PT Pupuk Kaltim, PT Pupuk Kujang, dan PT Petrokimia Gresik. Dipilihnya ketiga produsen pupuk tersebut karena ketiganya sudah mendapatkan sertifikasi ISO 14001:2015. Metode yang digunakan dalam studi ini adalah metode kualitatif dengan menganalisis dan menginterpretasikan data-data yang telah didapatkan. Hasil riset menunjukan bahwa strategi implementasi dalam pengelolaan lingkungan yang dilakukan oleh ketiga produsen pupuk tersebut tidaklah jauh berbeda, hampir semuanya memiliki kesamaan strategi dalam hal pengelolaan lingkungan, hanya saja PT Pupuk Kaltim memiliki kelebihan dalam pengelolaan lingkungannya dibandingkan kompetitornya. Hal ini dibuktikan dengan diraihnya PROPER gold tiga tahun berturut-turut, sedangkan PT Pupuk Kujang dan PT Petrokimia Gresik mendapatkan PROPER hijau.
\end{abstract}

Kata Kunci: ISO 14001:2015, implementasi, industri pupuk, PROPER, manajemen lingkungan

\section{Introduction}

Indonesia is known for a long time as an agricultural country. According to data from the Central Statistics Agency (BPS) in 2014, most of the land area in Indonesia, which is 71.33 percent, is used for agricultural businesses. In 2014 the area of land used for agriculture reached 44.95 million hectares [1]. Agriculture is one of the sectors offering a great contribution to the Indonesian economy. This is in line with the increasing demand for food commodities every year along with the rate of population growth, making the agricultural sector one of the mainstays and a serious concern needed to the development of farmers, land, agricultural technology, and fertilizers. Fertilizers as one of the supporting elements in the agricultural sector to increase the quality of agricultural products. 
As explained earlier, fertilizers as one of the supporting factors are commonly used in agricultural activities. The type of fertilizer that is popular to use in agriculture is inorganic fertilizers. Enhancement of the nutrient content in the soil can be obtained by applying inorganic fertilizers which are also useful in increasing agricultural production and the process of rapid plant growth. In the 1996-2006 period, around 5.97-7.34 million tons of fertilizer was produced, which increased an average of 3.52\% per year and made domestic fertilizer production varied [2]. The increase in the use of fertilizers was also recorded by the Ministry of Industry, where the total use of NPK fertilizers during 2018 was 2.80 million tons, an increase of $7.9 \%$ compared to the previous year, while the use of urea fertilizers was recorded at 6.27 million tons, an increase of $5 \%$ from the previous year [3].

Due to a large demand for fertilizer from domestic, the fertilizer industry is growing every year. Every fertilizer industry strives to provide the best quality to ensure customers' satisfaction. Not only in improving the quality of the product, but every fertilizer industry company also tries to implement an environmental management system to prevent pollution caused by the production process as well as a commitment to maintaining existing natural resources as a form of environmental compliance. In addition, many fertilizer industries have a strategy to manage the environment in order to get an ISO certification. As we know, ISO that organizes environmental management system is ISO 14001 [4]. They try to obtain the certification of ISO 14001 to earn customer trust that they have carried out the environmental management. The certification process is carried out through 2 stages of an initial certification audit, and subsequently a surveillance audit is carried out in the first and second years, and a re-certification audit in the third year [5]. The government through the ministry of environment established the company performance rating program in environmental management (PROPER) which has been implemented since 2002 in the field of impact control environment to increase the company's role in environmental conservation programs [6]. Gold, green, blue, red, and black are the five color levels PROPER rating is used to measure the environmental performance of companies in Indonesia, the highest environmental performance is indicated by the acquisition of a gold rating, while the lowest environmental performance is indicated by the acquisition of a black rating [7].

PROPER is the flagship program of the Ministry of Environment and Forestry to encourage industry compliance with environmental regulations. PROPER implementation has been arranged in Ministerial Regulation no. 3 of 2014 concerning PROPER [8]. Through Proper, the Government provides awards or incentives in the form of a good reputation to companies [9]. The implementation of PROPER is carried out on businesses and/or activities that are mandatory for EIA or UKL-UPL (Environmental Management and Monitoring Efforts), which a) the products are for export purposes, b) are available in the stock exchange market, c) are of public concern within the scope of regional and national, d) the scale of significant activities to have an impact on the environment [10]. The implementation of PROPER by the Ministry of Environment and Forestry is used to evaluate the company's environmental management, including waste management [11]. With this PROPER award, companies whose activities are likely have a large impact on the environment is expected to be more open or transparent in disclosure and reporting their environmental information [12].

The prerequisites for the environmental management system are set out in ISO 14001 and have been approved globally. in 1996, ISO 14001 was published. Designation of ISO 14001 that is directed in response to the latest trends and to ascertain whether this is compatible with other management system standards, and this has undergone changes until finally ISO 14001: 2015 is the latest version and it is necessary to upgrade the ISO to the latest version to replace the previous ISO that has been implemented in each company [13]. Since the update was issued in September 2015, organizations are given time to transition from the old standard to the version standard for 3 years, until September 2018 [14].

ISO 14001: 2015 provides a framework that makes future environmental management systems more effective to be followed by a company or organization. All activities or organizations can use a form of implementation ISO 1400: 2015, the use of ISO 14001: 2015 ensures that every impact on the environment can be measured and improved by the company, employees and stakeholders [15]. In 2015, more than 300,000 companies in the world were certified to ISO 14001. The high participation in the implementation of ISO 14001 is because ISO 14001 provides benefits [16]. The implementation of ISO 14001 can reduce the potential impacts on the environment such as reduce chemical spills, save the use of raw materials and natural resources, promote efficiency company business processes, improve the competitiveness of companies and build a positive image of the company in the government, business, and society (Ramadan et al., 2019). The application of environmental performance, environmental disclosure, and ISO 14001 are expected to have an impact on profitability so that the company's attention to environmental responsibility will be greater in the future. 
This study will discuss in detail an implementation of ISO 14001: 2015 in the fertilizer industry, and also would do comparative analysis of the strategies of environmental management systems selected among the fertilizer industry in the present study. The fertilizer industries selected in this study include: PT Pupuk Kaltim, PT Pupuk Kujang, and PT Petrokimia Gresik. Choosing the third fertilizer industry on the basis of a company that is large enough and long enough to compete in the fertilizer industry. For this reason, this study will analyse the implementation of ISO 14001: 2015 at each of the company and considering the companies have great potential that led to environmental pollution caused by production activities, and identify how much their compliance to environmental management refers to the legislation in force.

\section{Material and Methods}

The method used in this study is the qualitative method by analyzing and interpreting the secondary data obtained [17], especially the three last sustainability reports in the past two years issued by each company which contains information regarding the implementation of the environmental management system and environmental duty [18], as well as more than twenty scientific articles related to ISO 14001:2015 or environmental management system in the past six years. Furthermore, after all the necessary data has been obtained, the data will be analyzed and a comparison will be made between the implementation of an environmental management system at each company.

\section{Results and Discussion \\ 3.1. Company Profile \\ PT Pupuk Kaltim}

The company which has a vision "to become a world-class fertilizer, chemical, and agribusiness industry that grows sustainably" is located in Bontang, East Kalimantan. The company was established on October 31, 2008. It is considered as a quite capable company having a long experience as one of the largest producers in Indonesia. They produce and also distribute subsidized and non-subsidized fertilizers, providing products and services including; ammonia, urea, NPK fertilizer, biological products on a pilot scale. PT. Pupuk Kaltim has an annual production capacity of 3.43 million tons of urea, 2.74 million tons of ammonia, and 350 thousand tons of NPK (Sodium Phosphorus Potassium) [19].

In terms of the environmental management system, PT Pupuk Kaltim has been successful in carrying out environmental management and it wasproven by achieving a PROPER Gold rating for three consecutive years that is 2017, 2018, and 2019. Pupuk Kaltim is also the first fertilizer producer in Indonesia that received a green industry certificate from the Ministry of Industry of the Republic of Indonesia. With these achievements, it can be assumed that environmental management at PT Pupuk Kaltim is in accordance with existing standards, this is supported by obtaining ISO 14001: 2015 certification which is valid from 22 May 2019 - 25 May 2022 in the ammonia, urea, NPK production sector, and also laboratory testing services. In addition, PT Pupuk Kaltim also received another ISO certifications, including; ISO 9001: 2015, ISO 45001: 2018, and ISO 55001: 2014 (Pupuk Kaltim, 2019), and in 2008, Pupuk Kaltim received the Five Star Health and Safety Management System Audit award from the British Safety Council, England after successfully recording the achievement of zero accident (days without work accidents) of 21,929,128 working hours [21].

\section{PT Pupuk Kujang}

The company based in Cikampek, Karawang, West Java, was founded on June 9, 1975. PT Pupuk Kujang is a subsidiary of State-Owned Enterprises (BUMN). PT Pupuk Kujang is an industry that produces various kinds of fertilizers with more than 1062 employees in 2020 [22]. In terms of environmental management, Pupuk Kujang contributes to environmental preservation and control of climate change. Due to the increasing issue of climate change, Pupuk Kujang is committed to always put higher concern on managing the environment well and according to regulations with various policies and concrete actions implemented in the field.

The management of environmental aspects and impacts is the responsibility of the HSE (K3) department which has the task of ensuring that the Pupuk Kujang manages and complies with environmental aspects. In environmental management, Pupuk Kujang refers to the ISO 14001 standard which has been certified since 1998. Pupuk Kujang is certified ISO 14001: 2015 on January 30, 2018 which is valid until December 23, 2020. In addition, Pupuk Kujang has also received other certifications such as ISO 50001: 2011, ISO 9001: 2015, organic agriculture certification, green industry certificate, and other certifications. Owing to its compliance in managing the environment, Pupuk kujang received the PROPER award of green level predicate in 2012 until now. 


\section{PT Petrokimia Gresik}

A company which was founded on July 10, 1972, located in Gresik, East Java, is one of the oldest fertilizer producers in Indonesia. Same as other fertilizer industries, PT Petrokimia Gresik is under the auspices of the State-Owned Enterprises (BUMN) which initially produced ammonia, urea fertilizer, and ZA fertilizer. PT Petrokimia Gresik has received various awards in terms of environmental management, one of which is the GREEN PROPER award two years in a row in 2018-2019. 2019 was quite an exciting year for PT Petrokimia Gresik because it won 127 national and international awards. It is likely to be a significant increase considering that in 2017 only received 107 awards and 120 awards in 2018. Apart from awards, another significant aspect is certification, PT Petrokima Gresik received ISO 14001: 2015 certification on March 8, 2018, and is valid until March 7, 2021, other certifications that have been obtained include ISO 9001: 2015, ISO 50001: 2011, FSSC 22000 version 4.1, occupational safety and health management systems, etc.

A form of concern towards the environment has also been carried out through various kinds of implementations that refer to ISO 14001 regarding environmental management systems, PT Petrokimia Gresik is committed to contributing to the management and maintenance of environmental sustainability that is oriented towards the present and future generations, based on these problems PT Petrokimia Gresik strives to carry out environmentally friendly business practices as an effort to achieve sustainable development goals (SDGs). The practices that have been implemented in running an environmentally friendly business are as follows, efficiency in the use of materials so as to minimize the impact on the environment, efficiency in energy consumption, and others [24]. PT Petrokimia Gresik (PT PG) is committed to stakeholders outside the company through its CSR program [25].

\subsection{Environmental Management System Implementation \\ PT Pupuk Kaltim}

Not only complying with its obligations to environmental management, but PT Pupuk Kaltim also shows a form of concern and commitment to environmental preservation and improvement. The design and management of environmental aspects carried out by PT Pupuk Kaltim refer to various comprehensive regulations, as follows: UU no. 32 of 2009 concerning the protection and management of the environment, Law no. 30 of 2007 on energy, PP. 79 of 2014 concerning national energy policies, PP. 70 of 2009 concerning energy conservation, Minister of Energy and Mineral Resources Regulation No. 14 of 2012 concerning energy management, and Presidential Instruction No. 13 of 2011 on saving energy and water. The implementation of PT Pupuk Kaltim's environmental policy includes several important aspects, as follows (Pupuk Kaltim, 2019):

\section{Raw Material Management}

Efforts made by PT Pupuk Kaltim in terms of raw material processing are by making efforts to recycle raw materials. Given that the main raw materials for urea fertilizer production are natural gas, ammonia, and air, it is necessary to make efforts to recycle raw materials to increase energy efficiency. Efforts made by PT Pupuk Kaltim in the production process are recycling raw materials using the purge gas and flash gas recovery process from ammonia factory waste to become fuel gas, hydrogen gas, as well as Hydrogen Recovery Unit (HRU) and a purifier unit from ammonia products. A total of 7,276,483 gigajoules were recycled from raw materials.

\section{Energy Efficiency}

To make the energy efficiency program run properly, Pupuk Kaltim has carried out strict monitoring by using a production management system (SIMPRO), asset utilization, and Gap maintenance. Several energy efficiency program innovations have succeeded in obtaining energy efficiency of 13,168,194 Giga Joules in the last five years. The energy efficiency activities are as follows: 1. addition of NG condensate injection facility for ammonia 1A fuel primary reformer, 2. optimization of secondary fuel purifier ammonia factory 5, 3. optimizing usage of LP steam of ammonia 2 factory, 4. utilization of HRU-I fuel off gas for auxiliary fuel primary reformer, 5. method of maintaining urea concentration in final work unit at production rate above the standard, 6 . efficient use of electric energy in split air conditioning in office buildings, 7. revamping ammonia converter factory 3 from 5200 to 5300, 8. coal boilers as substitutes for gas boilers, 9. installation of photo cells to reduce the use of electricity energy on conveyor gallery in PCP 2871-V to 2879-V, 10. upgraded wood ward control governor 43027 to wood ward 50SE for optimizing the performance of $\mathrm{CO}_{2}$ compressor P-3, 11. making steam to carbon ratio optimization and primary reformer outlet temperature applications for $\mathrm{CH}_{4}$ leak to improve energy efficiency on plant 3, 12 . innovation of pressure air powered slurry pumps.

As additional information, Pupuk Kaltim has a power plant to meet energy needs so that it does not use indirect energy from PLN in the production process. In 2019, Pupuk Kaltim's energy use value was 
recorded at 53,936,849 gigajoules. In terms of energy management, Pupuk Kaltim is committed to implementing ISO 50001: 2015 for all factories. Energy conservation has also been carried out such as Reverse Osmosis (RO) which functions to replace the thermal desalination process, and uses HRU to utilize the ammonia factory exhaust gas. Energy conservation managed to save 4,317,491 gigajoules of energy in 2019.

\section{Management and Reduction of Greenhouse Gas}

There are three categories of activities that produce greenhouse gas emissions, namely direct greenhouse gas emissions, indirect greenhouse gas emissions, and other indirect greenhouse gas emissions. Various efforts have been made to reduce greenhouse gas emissions, including: installing cyclones, scrubbers, bag filters, and dedusting to exhaust chimneys to control air pollution. The installation of a Continuous Emission Monitoring System (CEMS) tool on several chimneys has also been carried out to monitor air emissions so that they do not exceed quality standards, CEMS is a tool used intended to measure the quantity level of an emission parameters in proportion and exhaust gas composition and flow rate emissions through continuous measurement [26].

There are 24 emission reduction programs that have been implemented, consisting of: 1 . utilization of ammonia plant condensate NG 1A, 2. cryogenic purification unit-5 ammonia plant, 3. optimizing the use of LP stream ammonia plant 2, 4. off fuel gas utilization HRU-1 for auxiliary fuel reformer primary ammonia factory, 5. application of RO (reverse osmosis) in plant 1 and plant 5, 6. $\mathrm{CO}_{2}$ utilization in the plants residual $\mathrm{CO}_{2}$ emergency bubbling pond, 7. repair air system, 8. improvement lighting system, 9 . improvement of electromagnetic system, 10. maintaining of method urea concentration in final work unit at the rate above production standards, 11. revamping ammonia converter of P-3 3 from s200 to s300, 12 . substitution of gas to coal boiler, 13. installation of photo cell to reduce electricity consumption on lighting for gallery conveyor PCP from $2871-\mathrm{V}$ to $2879-\mathrm{V}, 14$. upgrade from of wood ward control governor 43027 to wood ward 505E for optimizing the performance of $\mathrm{CO}_{2}$ compressor P-3, 15. optimization of stream ratio on primary reformer regarding to $\mathrm{CH}_{4}$ leak, 16. providing electricity from biodiesel (B100) for Malahing community, 17. pneumatic powered slurry pump, 18. precipalm (precision agriculture platform for oil palm), 19. substitution of diesel to B100 on production units of organic fertilizer and bio-decomposer, 20. substitution of low rank to medium rank coal, 21. modification of utilization of hp flash gas compressor to shorten startup time of ammonia plant 5, 22. maximizing demin mixbed polisher production and minimizing water and chemical use in demineralization unit, 23. optimization of flow purge gas to reduce energy consumption in ammonia-2 plants, 24. alternative electricity procurement using solar cell for CSV PKT KJA. The total volume of greenhouse gas emissions reduced by 707,354.94-tonnes of $\mathrm{CO}_{2}$ in 2019 .

\section{Water Conservation}

PT Pupuk Kaltim has made efforts to save water in the production process and other supporting units. Mainly, the programs carried out include recycling of waste from process water, managing well operations, and maintaining distribution pipes to prevent leaks. PT Pupuk Kaltim has carried out various initiative programs in water saving, which consist of: 1 . Reuse of condensate steam \& process, 2. Utilization of condensate chiller product cooler, 3 . RO desalination as a substitute for thermal desalination, 4 . Reducing the make-up of the NPK fusion process with NO ISOMEDI AIR PUMP applications, 5. Portable water savings, 6. Backwash filter water utilization. In 2019, a total of $5,051.0 \mathrm{~m}^{3}$ (eq ton) of water was saved, and the amount of waste that was successfully recycled was $11,921,789 \mathrm{~m}^{3}$.

\section{Waste Management and Utilization}

PT Pupuk Kaltim undertakes routine prevention and monitoring efforts, as they realize that each of their business activities has an impact on the environment. A total of Rp38.18 billion of funds will be allocated for waste management in 2019. Generally, there are three main wastes that are managed, which include waste water, B3 waste, and non-B3 waste.

a. Waste Water

The principle of In-Plant Treatment is used by Pupuk Kaltim in managing waste water, namely prioritizing the recycling of waste water which can still be used in the production process. Most of which comes from waste water treatment (WWT), processing of waste water in an emergency is carried out using an emergency pond which equipped with $\mathrm{CO}_{2}$ bubbling facilities. Waste water that has been managed will be flowed into the Makassar Strait. In terms of disposal of waste water into the sea, Pupuk Kaltim has a permit from the governor of East Kalimantan No. 503/1853 / LINK / BPPMDPTSP / IX / 2016 concerning Amendment to the Decree of the Governor of East Kalimantan Number 658.31 / K.638 / 2014 concerning the Granting of Permit for Disposal of Wastewater into the Sea to PT Pupuk Kaltim. Pupuk Kaltim monitors all waste water output to comply with the required quality standards. Besides conducting routine monitoring of the quality of wastewater discharge, monitoring 
of the community structure of plankton, benthos, and demersal fish was also carried out by Pupuk Kaltim as a parameter of damage to water bodies, and the result was that the water bodies around Pupuk Kaltim were stable.

b. B3 Waste

The 3R program is carried out in handling B3 waste, which includes: optimization of the production process, refilling packaging as a substitute for chemical packaging, decoking primary former catalysts, oil purification tools to reduce used oil generation, and the use of LED lights in office areas. In handling B3 waste, Pupuk Kaltim collaborates with licensed third parties. The results of the B3 waste reduction and utilization program in 2019 amounted to 340.16 tonnes. Pupuk Kaltim utilizes B3 waste coal ash into bricks and paving blocks which have received permission since December 28, 2016, totaling 5.3-tons of B3 fly ash waste has been used as material for brick making in 2019.

c. Non-B3 Waste

Office waste, organic waste, and inorganic waste are the main non-B3 waste generated from Pupuk Kaltim's operational activities. A total of 3,789.84-tonnes of non-B3 solid waste was generated in 2019. Pupuk Kaltim has implemented 5 programs for utilization and reduction of non-B3 waste, consisting of: 1. Composting, 2. Paper reduction, 3. Replacement size of NPK raw material packaging, 4. Utilization of used bags by third party, 5. Utilization of urea reject. About $84.8 \%$ of non-B3 waste has been successfully utilized, while the rest will be disposed of at the TPS.

\section{Biodiversity}

Pupuk Kaltim realizes how important it is to carry out a biodiversity protection program, because it is located directly adjacent to the Kutai National Park, Pupuk Kaltim has implemented a biodiversity protection program which includes: 1. Rare plant nurseries, 2. Conservation of endemic black orchids, 3. Conservation Sambar deer, 4. Rehabilitation of artificial reefs in Tobok Batang, 5. Mangrove planting in Kedindingan.

\section{PT Pupuk Kujang}

PT Pupuk Kujang committed to preserve the environment, contribute to make an effort to control climate change, as well as having a principle to make any small action that can lead to a positive impact on the environment. In terms of environmental management, Pupuk Kujang establishes environmental policies that are integrated with quality policies as well as occupational safety \& health aspects. Implementation of environmentally friendly production processes through sustainable environmental management activities also saving natural resources is a commitment of Pupuk Kujang as cleaner production efforts. Some of the efforts and policies of environmental management includes (Pupuk Kujang, 2019):

\section{Energy Efficiency}

The principles of conservation and efficiency are Pupuk Kujang's priorities in each of its operational activities. The energy management team is specially formed to establish a strategic plan related to energy efficiency and also conducts regular energy audits. Some of the energy efficiency programs that have been implemented in 2019 are as follows:

\section{Energy Management}

The applications are as follows: Setting the main energy use operation mode at shutdown and start up, optimizing the production process, using efficient raw materials, chemical cleaning plate heat exchanger program for $\mathrm{CO}_{2}$ removal area, optimizing the performance of the 2007-UA boiler control system.

a. Energy saving on Electronic Equipment

The implementation is as follows: street lighting and warehousing areas using solar cells, using energy-saving lamps and LEDs to replace street lighting, offices and housing.

b. Eco-Office Program

Some of the steps taken are as follows: turning off electronic devices during rest hours and when not in use, adjusting lighting and temperature of the workspace. As additional information, some of the efforts that have been made by Pupuk Kujang in energy efficiency include: replacement of K1B primary reformer catalyst, rotor cleaning and diaphragm GB 101-LP. The programs that have been implemented have succeeded in reducing energy consumption by 6,843,233 gigajoules.

\section{c. Water Consumption and Conservation}

Cikao river and Curug are two sources of raw water used for operational activities Pupuk Kujang. PT Pupuk Kujang continues to take initiatives in water conservation, because Pupuk Kujang realizes that the availability of clean water is getting less and less. Various efforts have been made to conserve water, including 4R activities, the use of environmentally friendly technology, making biopore infiltration holes, and planting trees. The more detailed explanation regarding each water conservation effort is as follows: 


\section{d. Water Conservation in Factory}

Water recycling is carried out for water makeup from the backwash and blowdown residue and the use of condensate for the process. Efforts to reuse water are also carried out from the blowdown process and condensate which is reused in other processes. Reduce efforts are carried out by replacing the use of chemicals in the cooling tower so that it will save the volume of water that is blowdown.

\section{e. Water Conservation in Non-Factory Activities}

The activities include: 1 . The construction and maintenance of a city park which turns out to be a new spring called the Kahuripan spring which is used by the surrounding community as daily clean water needs 2. Making biopores, with this program it can absorb water reaching 13,140 $\mathrm{m}^{3}$ in 2014 3. Utilizing a small river in the forest for demonstration rice fields managed by Pupuk Kujang 4. Utilizing rainwater storage ponds. PT Pupuk Kujang ensures that the waste water generated in the production process has been processed at the waste water treatment plant (WWTP) so that the waste water to be discharged into the Cikaranggelam river water bodies meets quality standards.

\section{Reduction of Greenhouse Gas Emissions}

One of the causes of climate change is greenhouse gas emissions. In relation to this, PT Pupuk Kujang realizes that their operational activities contribute to greenhouse gas emissions, this is in line with the IFA statement which estimates that fertilizers contribute to $2-3 \%$ of global greenhouse gas emissions. Pupuk Kujang has conducted a comprehensive inventory and data collection to determine the source of greenhouse gas emissions.

The IPCC (Intergovernmental Panel on Climate Change) method is used in the inventory of greenhouse gas emissions, and the GIS (Geographical Information System) method is used to determine the sampling coordinates. The policies adopted by PT Pupuk Kujang to reduce greenhouse gas emissions include sustainable production and sustainable consumption.

\section{Reduction and Utilization of B3 Waste and Non B3 Waste}

Pupuk Kujang already has a temporary storage permit for B3 waste issued by DPMPTSP Karawang Regency There are three locations that have temporary storage permits for B3 waste, namely TPS for solid B3 waste, B3 liquid waste, and used lubricant TPS. Furthermore, it will be submitted to a third party who has a permit to manage B3 waste. The 3R principle (Reduce, Reuse, Recycle) is carried out in the management of B3 waste. In terms of non-B3 solid waste management, it is carried out with a variety of initiatives that use the 3R principle (Reduce, Reuse, Recycle), and some non-B3 solid waste is used for community development programs in collaboration with SMAN 2 Cikampek and Eco Village Main Waste Bank Karawang.

\section{Biodiversity}

Pupuk Kujang allocates an area of about 60 hectares as a conservation forest area, this is a manifestation of Pupuk Kujang's commitment to environmental conservation. Pupuk Kujang protected forest is dedicated to storing biodiversity in the West Java region and is supported by the West Java Province BPLHD. Based on decree No.188 / Kep / .369-Huk / 2014 from the Regent of Karawang, the Pupuk Kujang forest is one of the Biodiversity Parks in West Java Province. Department of occupational, health and safety environment (OHSE) in charge of forest maintenance activities. The Pupuk Kujang forest area provides benefits to the surrounding community because it is a source of water that is used in daily life.

\section{PT Petrokimia Gresik}

PT Petrokimia Gresik applies environmentally friendly business practices, this relies on sustainable principles and to support the realization of sustainable development goals (SDGs). The application of environmentally friendly business practices refers to the applicable standards and is supported by the acquisition of the ISO 14001 certificate. The various implementations in environmentally friendly business practices are as follows [24]:

\section{Raw Material Management}

PT Petrokimia Gresik has made efforts in terms of raw material management, namely by recycling gypsum. In 2019, the amount of gypsum successfully recycled was $1,150,439$ tons.

\section{Energy Efficiency}

Energy efficiency efforts made by PT Petrokimia Gresik through energy conservation program initiatives which consist of:

a. Energy Conversion to Coal Program

MFO (Marine Fuel Oil) and natural gas are the fuels used in the operational activities of PT Petrokimia Gresik for steam and electricity generation. Petrokimia Gresik realizes that the availability of these two fuels is increasingly limited, then Petrokimia Gresik replaces the use of other alternative fuels, 
namely by using coal, with a capacity of 150 tons / hour as many as two boilers, stream turbine generator with the capacity of $25 \mathrm{MW}$, demin units. plant, cooling tower, and storage. A total of 3.1 million gigajoules of energy savings were achieved through this program.

b. Energy Optimization, Ammonia Vapor Feeding

Feeding vapor ammonia replaces the supply of liquid ammonia feed. This program achieves energy efficiency of 337,733 gigajoules / year. Process Optimization by Substituting High Pressure Steam (HPS) with Medium Pressure Steam (MPS) at 173-C Ammonia Plant. The energy savings achieved through this program amounted to 351,493 gigajoules / year, and this has the potential to reduce $\mathrm{CO}_{2}(\mathrm{GHG})$ emissions by 19,700-tonnes of $\mathrm{CO}_{2} /$ year.

c. Investment Grade Energy Audit (IGA) with Ministry of Energy and Mineral Resources

This energy audit is a partnership program with the Ministry of Energy and Mineral Resources, the recommendations resulted from this energy audit by replacing equipment such as the Dynamic Coal Classifier, adding Soot Blower, and Hydroblaster for cleaning.

d. Energy Audit at Buildings \& Offices

This energy audit resulted in several recommendations that essentially made the least effort on the energy used in buildings and offices.

e. Energy Conversion to Renewable Energy

Replacing street lights with solar cells, this program is able to save energy by $21,024 \mathrm{~kW} /$ year.

f. Purge Gas Utilization as Fuel Substitute at Package Boiler B-1102

The cost of saving energy that has been achieved is IDR 28.6 million / day through this program.

g. Heat Optimization in the IA Ammonia Factory Reformer Unit

The addition of Steam Coil 101-BC in the Ammonia IA Refroming Unit by adding a stream coil can save natural gas consumption by 0.08 mmscfd in 2019 .

\section{Greenhouse Gas Emission}

PT Petrokimia Gresik supports the government's efforts to reduce greenhouse gas emissions by applying low-carbon technology. The efforts made in the program to reduce greenhouse gas emissions include: providing facilities and infrastructure for controlling air pollution such as emission chimneys, installing Continuous Emission Monitoring (CEM) tools, and monitoring facilities and infrastructure for controlling air pollution.

\section{Management of B3 Waste and Non B3 Waste}

The addition of lime / caustic soda is done in wastewater management, $40 \%$ of the treated wastewater will be used in the production process, while $60 \%$ will be discharged into the sea. For B3 waste treatment, Petrokimia Gresik performs recycle processing and appoints a third party who has a license to handle B3 waste, while non-B3 waste will be disposed of directly to the TPA.

\section{Biodiversity}

The development of environmental areas is an effort made by PT Petrokimia Gresik on biodiversity. There are three protected species in the PT Petrokimia Gresik environmental area, namely the Bawean Deer (Axis kuhlii) and the Timor Deer (Cervus timorensis) and the Bawean Red Fruit (Diospyros blancoii). 


\begin{tabular}{|c|c|c|c|}
\hline \multirow{2}{*}{ Aspect of Implementation } & \multicolumn{3}{|c|}{ Company } \\
\hline & PT Pupuk Kaltim & PT Pupuk Kujang & PT Petrokimia Gresik \\
\hline Raw Material Management & 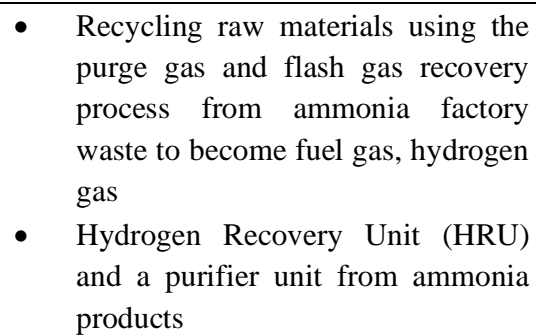 & Implementation not found & - $\quad$ Recycling gypsum \\
\hline Energy Efficiency & $\begin{array}{l}\text { - Strict monitoring by using a } \\
\text { production management system } \\
\text { (SIMPRO), asset utilization, and } \\
\text { Gap maintenance, through } 12 \\
\text { programs. }\end{array}$ & $\begin{array}{ll} & \text { Energy Management } \\
- & \text { Energy saving on Electronic Equipment } \\
\text { - } & \text { Eco-Office Program }\end{array}$ & $\begin{array}{l}\text { - Energy conservation program } \\
\text { initiatives which consist of } 8 \\
\text { programs. }\end{array}$ \\
\hline $\begin{array}{l}\text { Management and Reduction of } \\
\text { Greenhouse Gas }\end{array}$ & $\begin{array}{l}\text { - Installing cyclones, scrubbers, bag } \\
\text { filters, and dedusting to exhaust } \\
\text { chimneys to control air pollution } \\
\text { - The installation of a Continuous } \\
\text { Emission Monitoring System } \\
\text { (CEMS) tool on several chimneys } \\
\text { - } 24 \text { emission reduction programs }\end{array}$ & 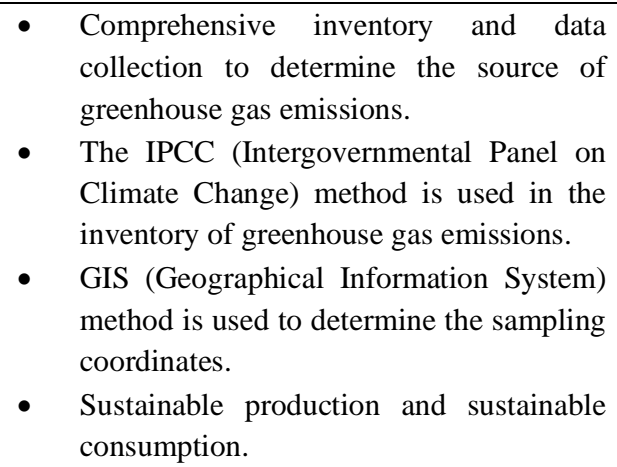 & $\begin{array}{ll}\text { - } & \text { Applying low-carbon technology } \\
\text { - } & \text { Providing facilities and infrastructure } \\
\text { for controlling air pollution } \\
\text { - Installing Continuous Emission } \\
\text { Monitoring (CEM) tools } \\
\text { - Monitoring facilities and } \\
\text { infrastructure for controlling air } \\
\text { pollution }\end{array}$ \\
\hline Water Conservation & 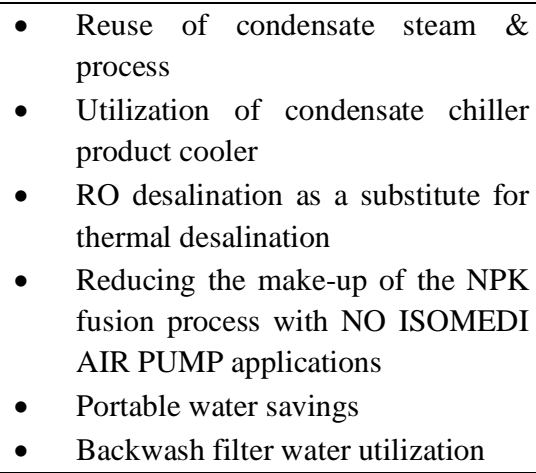 & $\begin{array}{l}\text { - Water Conservation in Factory: } 4 \mathrm{R} \\
\text { principles in the production process } \\
\text { - Water Conservation in Non-Factory } \\
\text { Activities: construction and maintenance } \\
\text { of a city park, biopores, utilizing a small } \\
\text { river in the forest. }\end{array}$ & Implementation not found \\
\hline
\end{tabular}


- Waste Water: The principle of InPlant Treatment, processing of waste water in an emergency is carried out using an emergency pond which equipped with $\mathrm{CO}_{2}$ bubbling facilities.

- $\quad$ B3 Waste: 3R program, utilizes B3 waste coal ash into bricks and paving blocks

- Non-B3 Waste: composting, paper reduction, replacement size of NPK raw material packaging, utilization of used bags by third party, utilization of urea reject

- $\quad$ Rare plant nurseries

- Conservation of endemic black orchids

Biodiversity

- Conservation Sambar deer

- Rehabilitation of artificial reefs in Tobok Batang

- Mangrove planting in Kedindingan
B3 Waste: 3R program

- Non-B3 Waste: 3R program, some nonB3 solid waste is used for community development programs.
- Waste Water: $40 \%$ of the treated wastewater will be used in the production process.
- Allocates an area of about 60 hectares as a conservation forest area.
- Development of environmental areas that are protected three species, Bawean Deer (Axis kuhlii) and the Timor Deer (Cervus timorensis) and the Bawean Red Fruit (Diospyros blancoii). 


\subsection{Analysis of environmental management system implementation among companies}

Based on each of the explanations described above regarding the implementation of an environmental management system in each company, almost all companies have the same implementation strategy in terms of environmental management. The implementation strategy is in accordance with existing standards, even each company has shown a commitment in terms of environmental management and improvement more than the compliance requirements in the relevant laws and regulations, this is supported by obtaining ISO 14001: 2015 certification by all related companies.

Energy Efficiency is the most prioritized aspect of the six implementation aspects studied, such as in PT Pupuk Kaltim. In this case, PT Pupuk Kaltim prioritizes the application of an energy management system by considering that energy consumption costs quite a lot, which is around $70 \%$ of the total production costs, and to meet the requirements of the PROPER assessment, owing to its compliance with environmental management, PT Pupuk Kaltim received PROPER Gold three years in a row. From the six implementation aspects studied, PT Pupuk Kaltim has carried out the implementation in all aspects. PT Pupuk Kujang prioritizes energy efficiency and conservation in each of its operational activities. From the six implementation aspects studied, PT Pupuk Kujang has carried out the real implementation in every operational activity, only the raw material management aspects which have not been founded.

Owing to its compliance with environmental management, PT Pupuk Kujang received the PROPER Green award since 2012 until now. Similar to other companies, PT Petrokimia Gresik also prioritizes energy efficiency in its operational activities, this can be seen from the discovery of eight programs in energy management. From the six implementation aspects studied, only the water conservation aspect which was not implemented. PT Petrokimia Gresik was awarded the PROPER Green award in 2018-2019.

\section{Conclusion}

To sum up, each company has shown its commitment to environmental management, all implementations have met the existing standards, energy efficiency is an implementation aspect that is prioritized in each company. Owing to the commitment and hard work of each company in environmental management, there are no reports of environmental damage due to the company's operations. All companies have ISO 14001: 2015 certification, and all companies have received the PROPER award, PT Pupuk Kaltim received PROPER Gold award, while PT Pupuk Kujang and PT Petrokimia Gresik received PROPER Green award.

\section{Acknowledgment}

Firstly, we would like to give our gratitude to God, and also thanks to our friends, due to their support so that we can finish this paper thoroughly.

\section{References}

[1] J. Agribisnis, F. Pertanian, U. Lampung, J. Prof, S. Brodjonegoro, and A. Tenggara, "JIIA, VOLUME 6 No. 3, AGUSTUS 2018," vol. 6, no. 3, pp. 249-256, 2018, doi: http://dx.doi.org/10.23960/jiia.v6i3.313-318.

[2] D. S. Irawan and S. Rochayati, "Proyeksi kebutuhan pupuk sektor pertanian melalui pendekatan sistem dinamis," Bogor, Balai Penelit. Tanah, no. 12, pp. 123-139, 2017, [Online]. Available: https://www.academia.edu/download/34465994/09_-_Irawan_et_al_-

_Proyeksi_Kebutuhan_Pupuk_Sektor_Pertanian_Melalui_Pendekatan_Sistem_Dinamis.pdf.

[3] J. S. Adiansyah, N. P. Ningrum, D. Pratiwi, and H. Hadiyanto, "Kajian Daur Hidup (Life Cycle Assessment) dalam Produksi Pupuk Urea: Studi Kasus PT Pupuk Kujang," J. Ilmu Lingkung., vol. 17, no. 3, p. 522, 2019, doi: 10.14710/jil.17.3.522-527.

[4] M. Gunawan, R. Asyahira, and F. M Sidjabat, "Environmental Management System Implementation in MSMEs: A Literature Review," J. Serambi Eng., vol. 5, no. 2, pp. 1070-1078, 2020, doi: 10.32672/jse.v5i2.1958.

[5] E. Larantukan, E. Suswantoro, and D. Hendrawan, "Tingkat Pengetahuan dan Kesadaran Karyawan terhadap Penerapan Sistem Manajemen Lingkungan (SML) ISO 14001:2004 di PT Garuda Metalindo," Semin. Nas. Pembang. Wil. dan Kota Berkelanjutan, vol. 1, no. 1, pp. 187-195, 2019, doi: 10.25105/pwkb.v1i1.5276.

[6] M. S. Evita, "Terhadap Kinerja Keuangan Perusahaan Pertambangan Studi Kasus Pada Bursa Efek Indonesia Tahun 2014-2017 Effect of Environmental Environment, Environmental Performance , and Iso 14001 on Mining Company Financial Performance Case Study in Indonesia Stock E," vol. 13, no. 1, pp. 27-35, 2019. 
[7] R. I. Adyaksana and B. G. Pronosokodewo, "Apakah Kinerja Lingkungan dan Biaya Lingkungan Berpengaruh Terhadap Pengungkapan Informasi Lingkungan?," InFestasi, vol. 16, no. 2, pp. 157165, 2020, doi: 10.21107/infestasi.v16i2.8544.

[8] R. Fahmawati and H. Purnaweni, "Implementasi Kebijakan Program Penilaian Peringkat Kinerja Perusahaan Dalam Pengelolaan Lingkungan Hidup (PROPER) di Kota Semarang," J. Public Policy Manag. Rev., vol. 8, no. 1, pp. 128-141, 2018.

[9] F. Rahman, "Penanggulangan Kebakaran Hutan dan Lahan Melalui Instrumen Penaatan Sukarela: (Suatu Tinjauan Dalam Kebijakan Proper Lingkungan) Oleh : Faisol Rahman * 1," no. October, 2019.

[10] T. Wikaningrum, B. Pramudya N, and E. Noor, "The Policy of Industrial Estate Environmental Management Complying to the Green Rating of 'PROPER KLHK' (The Case Study in Jababeka Industrial Estate)," J. Nat. Resour. Environ. Manag., vol. 5, no. 2, pp. 111-120, 2015, doi: 10.19081/jpsl.5.2.111.

[11] B. S. Q. Faizah, "Penerapan Green Accounting Terhadap Kinerja Keuangan," J. Ris. Akunt. Kontemporer, vol. 12, no. 2, pp. 94-99, 2020.

[12] P. P. Sarjana and J. Akuntansi, "Determinan pengungkapan lingkungan: perspektif anugerah proper artikel ilmiah," 2020.

[13] F. M. Sidjabat, R. Habibah, and M. Pasaribu, "Comparative Analysis of Quality and Environmental Management Strategic Implementation in Cement Industry," Media Ilm. Tek. Lingkung., vol. 4, no. 2, pp. 58-70, 2019, doi: 10.33084/mitl.v4i2.1072.

[14] C. P. Maryeska, D. R. Jati, and S. Pramadita, "Analisis Transisi Penerapan Sistem Manajemen Lingkungan ISO 14001 Versi 2015 (Studi Kasus : PT.AZ) (Transition Analysis on Application of The Environmental Management System ISO 140012015 Version (Case Study: PT. AZ))," J. Teknol. Lingkung. Lahan Basah, vol. 8, no. 1, p. 001, 2020, doi: 10.26418/jtllb.v8i1.39119.

[15] H. Riaz, A. Saeed, M. Baloch, Nasrullah, and Z. Khan, "Valuation of Environmental Management Standard ISO 14001: Evidence from an Emerging Market," J. Risk Financ. Manag., vol. 12, no. 1, p. 21, 2019, doi: 10.3390/jrfm12010021.

[16] R. Kurniawan, S. Hasibuan, and R. E. Nugroho, "Kurniawan At All 252 - 266 MIX: Jurnal Ilmiah Manajemen, Volume VII, No. 2, Juni 2017," Mix J. Ilm. Manaj., vol. VII, no. 2, pp. 252-266, 2017.

[17] G. Givano, H. Sholichah, and F. M. Sidjabat, "Implementation of Iso $9001: 2015$ and Iso $14001: 2015$ in Coal and Heavy Metal Mining Sector: Study Case," J. Sains dan Teknol. Lingkung., vol. 11, no. November 2018, pp. 57-73, 2019.

[18] P. P. P. Tbk, K. Jababeka, and B. Indonesia, "The Comparison of ISO 14001 Implementation in Indonesia Construction Companies ( Case Study : PT . Waskita Karya Tbk, PT . Wijaya Karya Tbk, PT .," vol. 5, no. 2, pp. 120-127, 2020.

[19] J. Ilmiah, T. Sipil, P. N. Samarinda, J. T. Sipil, P. N. Samarinda, and K. Samarinda, "Kajian pondasi tiang pancang pada dermaga khusus pt. pupuk kaltim," vol. 13, no. 1, pp. 36-42, 2021.

[20] P. T. Pupuk and K. Timur, "MEningkatkan kontribusi pada pencapaian tujuan keberlanjutan," 2019.

[21] A. N. Amalita, "Pengaruh Program Keselamatan dan Kesehatan Kerja Terhadap Kepuasan Kerja dan Kinerja Karyawan ( Studi Pada Karyawan Kompartemen Operasi I dan II PT Pupuk Kaltim ),” J. Adm. Bisnis, vol. 28, no. 1, pp. 100-108, 2015.

[22] B. N. Aprilia and S. Hersona, "YUME : Journal of Management Pengaruh Stres Kerja dan Kepuasan Kerja terhadap Kinerja Karyawan pada PT . Pupuk Kujang Cikampek,” vol. 4, no. 2, pp. 273-282, 2021, doi: 10.37531/yume.vxix.x655.

[23] L. Keberlanjutan and S. Report, "Mewujudkan Industri Berwawasan Lingkungan untuk Kesejahteraan Bersama."

[24] Petrokimia Gresik, "Laporan Berkelanjutan,” J. Chem. Inf. Model., vol. 53, no. 9, pp. 1689-1699, 2019.

[25] I. M. Narsa and A. Irwanto, "Implementasi Tanggung Jawab Sosial PT Petrokimia Gresik pada Masyarakat Lokal: Apa Kata Mereka?," J. Akunt. Multiparadigma, vol. 5, no. 3, 2014, doi: 10.18202/jamal.2014.12.5034.

[26] E. N. Conference., "Monitoring Emisi SO2 Menggunakan Continuous Emission Monitoring System (CEMS ) Berbasis Programmable Logic Control (PLC) Pada Operasional Produksi Terak di PT Semen," pp. 24-32, 2017. 